\title{
Public Health Perspective on Magnesium
}

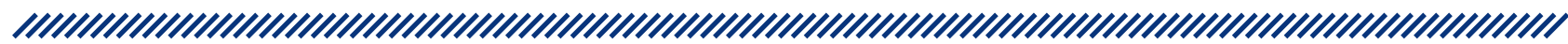

1 Lidija Šoher

1 Ines Banjari

1 Department of Food and Nutrition Research, Faculty of Food Technology, Josip Juraj Strossmayer University of Osijek, Croatia magnesium intake, especially among physically active individuals. Public awareness of the health benefits gained from physical activity is improving, and more individuals decide to engage in (recreational) physical activity. Even though physical activity increases the risk of magnesium deficiency, misuse of supplements due to lack of knowledge and misinformation shared on social networks can have a detrimental effect on individual's health and physical performance.

\section{Abstract}

Magnesium is a cofactor in more than 300 enzymes, it plays a vital role in energy metabolism, homeostasis of electrolites, and bone metabolism, and regulates a number of fundamental functions such as muscle contraction, neuromuscular conduction, glycemic control, and blood pressure. Magnesium deficiency has been associated with a wide range of diseases, from cardiovascular diseases, hypertension, diabetes, to anxiety and other mental disorders, migraine and osteoporosis, and especially worrying is subclinical form which is estimated to affect up to $30 \%$ of the population. Recommended dietary intake of magnesium is $300 \mathrm{mg}$ and 350 mg per day for adult males and females, respectively. While highly abundant in a variety of foods, especially green leafy vegetables, nuts and seeds, water is the main contributor to magnesium daily intake. Water has been the focus of a number of public health interventions aiming to improve magnesium status of populations, especially in Israel and Australia. Supplements are becoming a more important contributor to the total
Keywords: magnesium, deficiency, public health, water, physical activity

Article received: 12.02 .2021 .

Article accepted: 15.03.2021.

https://doi.org/10.24141/1/7/2/10

Corresponding author:

Ines Banjari

A: F. Kuhača 20, 31000 Osijek, Croatia

E-mail:ibanjari@ptfos.hr

T: +38531224339 


\section{Introduction}

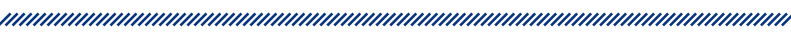

Magnesium (Mg) is an important cation and essential mineral with numerous functions in the body ${ }^{1,2}$. It is a crucial factor for over 300 enzymatic reactions including DNA, RNA, protein and adenosine-triphosphate (ATP) synthesis, cellular energy production and storage, glycolysis and cellular second messenger systems. Magnesium regulates cellular ion channels, transporters and signaling, which is especially important for calcium, potassium and sodium balance ${ }^{1-4}$. This effect is probably most evident with muscle cramps, the main symptom of Mg deficiency. Muscle contracts when depolarization of skeletal muscle cell occurs with sodium/ calcium exchange across the membrane. After muscle contraction calcium pump, via ATPase, which is Mg dependant, transports calcium ions to sarcoplasmic reticulum for storage. In case of Mg deficiency, prolonged retention of calcium manifests itself as muscle cramps and fatigue ${ }^{5-7}$.

Mg's functions are closely interrelated with other electrolytes. For example, sodium, potassium and chloride create positive gradient for the paracellular permeability and enable cations like $\mathrm{Mg}$ and calcium to enter the cell. $\mathrm{Mg}$ is involved in sodium and potassium balance, evident through occurrence of hypokalemia and hypokalcemia with Mg deficiency ${ }^{8}$.

Change in Mg homeostasis in the body may result in a deficiency which has been implicated in several clinical conditions ${ }^{9}$, including cardiovascular disease ${ }^{10}$, diabetes $^{11}$, essential hypertension ${ }^{12,13}$, anxiety disorders ${ }^{14}$, migraine ${ }^{15}$, and osteoporosis ${ }^{16}$. For all essential nutrients, focus is always on their recommended intake, absorption, possible deficiency or excessive intake and their aftermath on the public health. Even though severe $\mathrm{Mg}$ deficiency is considered to be rare, growing number of research supports the idea that Mg deficiency is an important risk factor for many non-communicable and cronic inflammatory diseases ${ }^{1-4,10,17,18}$. In average 10 to $15 \%$ of body's $\mathrm{Mg}$ is lost by sweat ${ }^{7}$. Therefore, athletes and physically active people are considered to be at higher risk of $\mathrm{Mg}$ deficiency in comparison to other population groups ${ }^{19}$.

\section{Magnesium Body Homeostasis}

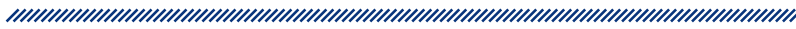

Following calcium, sodium and potassium, $\mathrm{Mg}$ is the fourth most abundant cation in the body and the second most abundant intracellular cation. There are at least three body pools of $\mathrm{Mg}$ in humans. About $60 \%$ of body $\mathrm{Mg}$ is found in bones, $40 \%$ is found in soft tissues, mostly muscles, where Mg preforms most of its essential functions and blood, which contains about $1 \%$ of $\operatorname{Mg}^{1,2,20}$ (Table 1).

\begin{tabular}{|c|c|}
\hline $\begin{array}{c}\text { Table 1. Distribution of magnesium in } \\
\text { healthy adults (prepared according to 4,7) }\end{array}$ \\
\hline Tissue & \% total body Mg \\
\hline Bones & $60-65$ \\
\hline Muscles & 27 \\
\hline Other cells & $6-7$ \\
\hline Extracellular & $<1$ \\
\hline Serum & $0.75-1.1 \mathrm{mmol} / \mathrm{L}$ \\
\hline Cerebrospinal fluid & $1.25 \mathrm{mmol} / \mathrm{L}$ \\
\hline Sweat & $0.3 \mathrm{mmol} / \mathrm{L}$ \\
\hline
\end{tabular}

On average, $\mathrm{Mg}$ reserves in a healthy adult weighing 70 $\mathrm{kg}$ is $24 \mathrm{~g}^{5,19} .90 \%$ of $\mathrm{Mg}$ is mainly bound to nucleic acids, ATP, negatively charged phospholipids and proteins, acting as a structural stabilizator and/or enzyme activator/inhibitor (ATPase, phosphofructokinase, adenylate cyclase, DNA polymerase, ect.) and about $10 \%$ is in free form ${ }^{4,21-23}$.

Magnesium can be absorbed by passive paracellular diffusion and active transport in all parts of the intestine, with a maximum absorption in distal jejunum and ileum. $80-90 \%$ is absorbed by the tight-junction passive diffusion ${ }^{1,4}$. Importantly, only free $\mathrm{Mg}$ can be absorbed via the paracellular pathway. The amount of $\mathrm{Mg}$ in food appears to be the main determinant when it comes to absorption ${ }^{2}$, i.e. the more $\mathrm{Mg}$ is consumed the less is absorbed. For example, the highest absorption is achieved at a very low dietary intake $(40 \mathrm{mg} /$ day) while consumption of $\mathrm{Mg}$ near the recommended intake (around $300 \mathrm{mg} /$ day) will result in $30-50 \%$ absorption ${ }^{20}$. Availability of $\mathrm{Mg}$ will regulate absorption mechanism; higher availability means that $90 \%$ of $\mathrm{Mg}$ will be absorbed via passive diffusion while low availability activates active transport via TRPM6 found in the 
colon ${ }^{1}$. TRPM 6 is a divalent cation channel that is tightly regulated by intracellular Mg2+ concentrations. After absorption through basolateral side of intestinal cell $\mathrm{Mg}$ is delivered to blood via $\mathrm{Na}+-$ dependent $\mathrm{Na}+\mathrm{Mg} 2+$ exchanger ${ }^{1}$. Absorption is also dependent on the intake of antinutrients, like fiber rich food - phytates, organic acids, polyols, calcium, phosphorus, polyphenols, oxalates, zinc, etc. ${ }^{24}$.

Besides intestinal absorption, bone stores and kidneys coordinate Mg homeostasis ${ }^{1,2,20,23,25}$. With a normal serum $\mathrm{Mg}$ concentration of 1.8 to $2.3 \mathrm{mg} / \mathrm{dL}$ and normal glomerular filtration rate, $70 \%$ of circulating Mg (2400 $\mathrm{mg}$ ) is filtered by glomeruli. Only $100 \mathrm{mg}$ of $\mathrm{Mg}$ is excreted, while the remaining $2300 \mathrm{mg}$ is reabsorbed along the kidney tubules by several coordinated transport processes. Only $30 \%$ of the filtered $\mathrm{Mg}$ is reabsorbed by the proximal tubule ${ }^{1,2}$. Besides urinary excretion, surface loss (through sweat) can be a significant contributor to $\mathrm{Mg}$ deficiency, especially when dietary consumption does not meet the recommendations ${ }^{1}$.

Changes in Mg homeostasis are generally recognized as hypermagnesemia or hypomagnesemia, the latter being more prevalent. Change in any of the aforementioned mechanisms of $\mathrm{Mg}$ body homeostasis will result in (pre)clinical deficiency ${ }^{26}$. Clinical diagnosis of $\mathrm{Mg}$ deficiency is not simple, as symptoms associated with $\mathrm{Mg}$ deficiency are unspecific, and generally confounded by low consumption of other nutrients. Some of the most common symptoms include fatigue, muscle spasms, weakness, constipation, and depression ${ }^{23,26}$. On the other hand, hypermagnesemia caused by some kidney disease or excessive oral ingestion (usually through supplementation) may cause nausea, vomiting or diarrhea, lethargy or headaches ${ }^{23}$.

\section{Dietary Sources and Recommendations}

Ever since Mg deficiency has been first described in year 1969, ${ }^{3,27}$ dietary recommendations for Mg changed. Table 2 shows current recommendations for all population groups.

Though only $10 \%$ of $\mathrm{Mg}$ is excreted, given its immense importance in all, but especially musco-sceletal functions, one's diet is the main source of $\mathrm{Mg}$. Mg is ubiqui- tous in commonly available foods, but especially good sources are green leafy vegetables, grains, nuts, beans, peas, and seeds (Table 3). Water, both tap and bottled, despite variable content of $\mathrm{Mg}$ also represent important source of $\mathrm{Mg}^{2}$.

\begin{tabular}{|c|c|c|}
\hline $\begin{array}{l}\text { Life stage } \\
\text { group }\end{array}$ & $\begin{array}{l}\text { Adequate } \\
\text { intake (AI) } \\
\text { mg/day }\end{array}$ & $\begin{array}{c}\text { Tolerable } \\
\text { Upper Intake } \\
\text { Level (UL) } \\
\text { mg/day }{ }^{\mathrm{a}}\end{array}$ \\
\hline \multicolumn{3}{|l|}{ Infants } \\
\hline \multicolumn{3}{|l|}{ Children } \\
\hline $1-2$ years & 170 & ND \\
\hline 3 years & 230 & ND \\
\hline $\begin{array}{l}4-9 \text { years } \\
10-17 \text { years }\end{array}$ & 230 & 250 \\
\hline Female & 250 & 250 \\
\hline Male & 300 & 250 \\
\hline \multicolumn{3}{|l|}{ Adults } \\
\hline$\geq 18$ years & 300 & 250 \\
\hline Female & 350 & 250 \\
\hline Male & 300 & 250 \\
\hline $\begin{array}{l}\text { Pregnancy } \\
\text { Lactation }\end{array}$ & 300 & 250 \\
\hline \multicolumn{3}{|c|}{$\begin{array}{l}\text { a The UL applies to readily dissociable Mg salts (e.g., chloride, } \\
\text { sulphate, aspartate, lactate) and compounds like } \mathrm{MgO} \text { in food } \\
\text { supplements, water or added to foods; does not include } \mathrm{Mg} \\
\text { naturally present in foods and beverages }\end{array}$} \\
\hline
\end{tabular}

Today, dietary supplements represent another important source of $\mathrm{Mg}$, usually in a form of aspartate, chelate, citrate, chloride, gluconate, lactate, or oxide ${ }^{2}$. The most common form of supplemental $\mathrm{Mg}$ are granules (intended for an instant, direct effect) or as effervescent tablets, usualy in combination with vitamins B, i.e. vitamin B6 (Hermes Biolectra ${ }^{\circledR}$ Magnezij Direkt 300 mg; Diethpharm $^{\circledast}$ Magnesium night; Natural Wealth ${ }^{\circledast}$ Magnezij direkt 375 mg + B + C; Natural Wealth ${ }^{\circledR}$ Magnezij Sport Direkt $+\mathrm{B} 6+\mathrm{C}+\mathrm{L}$-karnitin; etc.). Vitamin B6 facilitates the cellular uptake of $\mathrm{Mg}$ by limiting its excretion and increasing its effectivnes, i.e. in ratio 10:1 vitamin B6 was found to provide faster relief of Mg-deficiency symptoms ${ }^{30}$. The Tolerable Upper Intake Level (UL) is set at $250 \mathrm{mg}$ of supplementary Mg for adults and children older than 9 years ${ }^{28}$. 


\section{Water as a Contributor to Magnesium Intake}

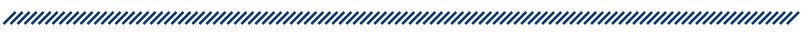

Water intake is essential for life and body functions, like metabolism, substrate transport across membranes, cellular homeostasis, temperature regulation and circulatory function ${ }^{31,32}$. Water requirements vary between individuals and environmental conditions, but European Food Safety Authority set the adequate total water intakes for females at $2.0 \mathrm{~L} /$ day and $2.5 \mathrm{~L} /$ day for males in $2010^{33}$. Given the amount of water consumed daily (Table 4), it represents the main source of $\mathrm{Mg}$. We still lack strong evidence regarding consumption and contribution of drinking water to the overall $\mathrm{Mg}$ and other mineral intake, as well as specific analysis for vulnerable population groups, just as it was outlined in the World Health Organization expert report from $2009^{34}$. An additional aspect that needs attention is that drinking water is not consumed as water per se but as a part of beverages and incorporated into foodstuffs ${ }^{34}$, which represents another major research challenge ${ }^{34,36}$.
According to the EFSA Comprehensive European Food Consumption Database ${ }^{37}$ average consumption of drinking water, both bottled and unbottled, in Europe is $756.59 \mathrm{~g} /$ day, and $1214.52 \mathrm{~g} /$ day in Croatia. Drinking water mainly comes from groundwater sources ${ }^{36}$ on which public water supply relies. According to the WHO, residents in Italy, Iceland, Austria, Denmark and Lithuania consume close to $90 \%$ of their water from groundwater sources, whereas people in France, Sweden and Finland consume up to $50 \%$, similarly to the Netherlands and Germany, at $50-70 \%$. The contribution of groundwater to water supply in the United Kingdom ranges from 30\% to $35 \%$, while only $15 \%$ in Norway ${ }^{34}$. Data for Croatia are in line with other EU countries ${ }^{37}$ (Table 4).

Geological site of a spring will determine Mg's content in water (Table 5). On average, Mg's content in ground water is around $50 \mathrm{mg} / \mathrm{L}^{38}$, differing significantly between soft and hard water ${ }^{38,39}$. For example, based on the recommended consumption of $2.0 \mathrm{~L}$ of water/day/ adult, for those living in the city of Zagreb tap water would contribute with only $40 \mathrm{mg}$ of $\mathrm{Mg}$ to their daily consumption, since $\mathrm{Mg}$ concentration is only $21.8 \mathrm{mg} / \mathrm{L}^{36}$.

Water supply is becoming a major issue, so many countries rely on bottled water ${ }^{34,40}$. Consumption of bottled

\begin{tabular}{|c|c|c|c|}
\hline & \multicolumn{3}{|c|}{ Table 3. Magnesium content in selected foods ${ }^{\mathbf{2 9}}$} \\
\hline Food & $\begin{array}{c}\text { Magnesium content } \\
(\mathrm{mg} / 100 \mathrm{~g})\end{array}$ & Food & $\begin{array}{c}\text { Magnesium content } \\
(\mathrm{mg} / 100 \mathrm{~g})\end{array}$ \\
\hline Swiss chard & $65 \mathrm{mg}$ & Kale & $20 \mathrm{mg}$ \\
\hline Spinach & $56 \mathrm{mg}$ & Brussels sprouts & $19 \mathrm{mg}$ \\
\hline Bananas & $42 \mathrm{mg}$ & Peas & $27 \mathrm{mg}$ \\
\hline Almonds & $260 \mathrm{mg}$ & Sweet corn & $46 \mathrm{mg}$ \\
\hline Walnut & $380 \mathrm{mg}$ & Wheat bran & $520 \mathrm{mg}$ \\
\hline Beans, white & $180 \mathrm{mg}$ & Sesame seeds & $354 \mathrm{mg}$ \\
\hline Wheat bran & $520 \mathrm{mg}$ & Figs, dried & $92 \mathrm{mg}$ \\
\hline Wholegrain bread, graham & $93 \mathrm{mg}$ & Dates, dried & $59 \mathrm{mg}$ \\
\hline
\end{tabular}

\begin{tabular}{|c|c|c|c|c|}
\hline & \multicolumn{4}{|c|}{ Drinking water (g/day) } \\
\hline & \multirow{2}{*}{\multicolumn{2}{|c|}{$\begin{array}{c}\text { Bottled water } \\
\text { Natural mineral water }\end{array}$}} & \multicolumn{2}{|c|}{ Unbottled water } \\
\hline & & & \multirow[b]{2}{*}{ Tap water } & \multirow[b]{2}{*}{ Well water } \\
\hline & $\begin{array}{l}\text { Carbonated natural } \\
\text { mineral water }\end{array}$ & $\begin{array}{c}\text { Still natural mineral } \\
\text { water }\end{array}$ & & \\
\hline Mean & 240.08 & 248.63 & 1092.54 & 903.47 \\
\hline Standard deviation & 244.52 & 423.66 & 682.02 & 587.52 \\
\hline Median & 166.67 & 333.33 & 1072.73 & 816.67 \\
\hline
\end{tabular}


Table 5. Electrolyte content (mg/L) of some bottled waters from Croatian market

\begin{tabular}{|c|c|c|c|c|c|c|c|c|}
\hline $\begin{array}{c}\text { Bottled water, } \\
\text { Natural mineral water }\end{array}$ & $\begin{array}{c}\mathrm{Mg}^{2+} \\
(\mathrm{mg} / \mathrm{L})\end{array}$ & $\begin{array}{c}\mathrm{Na}^{2+} \\
(\mathrm{mg} / \mathrm{L})\end{array}$ & $\begin{array}{c}\mathrm{Ca}^{2+} \\
(\mathrm{mg} / \mathrm{L})\end{array}$ & $\begin{array}{c}\mathrm{K}^{+} \\
(\mathrm{mg} / \mathrm{L})\end{array}$ & $\begin{array}{l}\mathrm{HCO}_{3}^{-} \\
\left(\mathrm{mg} / \mathrm{L}^{-}\right)\end{array}$ & $\begin{array}{c}\mathrm{Cl}^{-} \\
(\mathrm{mg} / \mathrm{L})\end{array}$ & $\begin{array}{c}\mathrm{SO}_{4}^{2-} \\
(\mathrm{mg} / \mathrm{L})\end{array}$ & $\begin{array}{c}\mathrm{F}^{-} \\
(\mathrm{mg} / \mathrm{L})\end{array}$ \\
\hline \multicolumn{9}{|c|}{ Carbonated natural mineral water } \\
\hline Mg Mivela (slightly carbonated) & 343.9 & 121.0 & 23.8 & 9.9 & 2037.5 & 14.2 & 0.9 & 0.4 \\
\hline Mg Mivela (carbonated) & 343.0 & 131.9 & 22.1 & 9.5 & 2064.8 & 14.4 & $<0.3$ & 0.4 \\
\hline Kalnička & 23.0 & 650.0 & 62.0 & 8.0 & 1410.0 & 350.0 & - & - \\
\hline Sarajevski Kiseljak & 41.3 & 598.0 & 248.5 & 16.8 & 1805.6 & 95.7 & 490.0 & - \\
\hline Lipički studenac & 26.4 & 101.0 & 72.5 & 13.3 & 493.0 & 51.2 & 31.3 & 1.2 \\
\hline Jamnica & 43.0 & 805.0 & 114.0 & 27.1 & 2246.0 & 262.0 & 116.1 & 0.9 \\
\hline Donat Mg & 1000.0 & 1500.0 & 390.0 & - & 7500.0 & 75.0 & 2200.0 & - \\
\hline Radenska & 82.0 & 480.0 & 190.0 & 75.0 & 2700.0 & 58.0 & 97.0 & 0.5 \\
\hline Average & 237.8 & 548.4 & 140.4 & 22.8 & 2532.1 & 115.1 & 489.2 & 0.7 \\
\hline Standard deviation & 336.9 & 469.8 & 128.5 & 23.9 & 2111.1 & 123.3 & 856.5 & 0.4 \\
\hline Min & 23.0 & 101.0 & 22.1 & 8.0 & 493.0 & 14.2 & 0.9 & 0.4 \\
\hline Max & 1000.0 & 1500.0 & 390.0 & 75.0 & 7500.0 & 350.0 & 2200.0 & 1.2 \\
\hline \multicolumn{9}{|c|}{ Still natural mineral water } \\
\hline Radenska & 20.0 & 7.4 & 59.0 & 0.8 & 280.0 & 4.4 & $<1$ & $>0.20$ \\
\hline Jana & 32.0 & 1.8 & 63.8 & 0.6 & 381.0 & 2.9 & 7.2 & 0.02 \\
\hline Studena & 26.8 & 11.4 & 79.0 & 1.1 & 400.0 & 4.1 & 3.3 & 0.21 \\
\hline Santa & 7.7 & 1.9 & 0.4 & 67.9 & 242.8 & 2.90 & 7.30 & 1.92 \\
\hline Kala & 19.0 & 7.0 & 87.0 & - & 378.0 & - & 11.0 & - \\
\hline Sveti Rok & 9.9 & 1.2 & 47.6 & 0.3 & 189.1 & 1.7 & 2.3 & 0.02 \\
\hline Cetina & 1.2 & 1.9 & 76.2 & 0.4 & 238.5 & 3.3 & 3.42 & 0.038 \\
\hline Average & 16.7 & 4.7 & 58.9 & 11.9 & 301.3 & 3.2 & 5.75 & 0.44 \\
\hline Standard deviation & 11.0 & 4.0 & 29.1 & 27.5 & 84.1 & 1.0 & 3.33 & 0.83 \\
\hline Min & 1.2 & 1.2 & 0.4 & 0.3 & 189.1 & 1.7 & 2.30 & 0.02 \\
\hline Max & 32.0 & 11.4 & 87.0 & 67.9 & 400.0 & 4.4 & 11.00 & 1.92 \\
\hline
\end{tabular}

water has been growing steadily for the past 30 years, and it is now the most dynamic sector of the entire food and beverage industry globally ${ }^{34}$. Like tap water, bottled water has variable $\mathrm{Mg}$ concentrations, as shown in Table 5. Bottled waters on the Croatian market have an $\mathrm{Mg}$ content from 23 to $1000 \mathrm{mg} / \mathrm{L}$ for carbonated and from 1.16 to $32.0 \mathrm{mg} / \mathrm{L}$ for still water. Though some of these types of water may cause symptoms of hypermagnesiemia, it should be noted that they are advertised as constipation relievers.

\section{Magnesium Deficiency as a Public Health Issue}

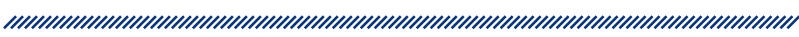

Public health significance of water as the main source of Mg is nicely summarized in the WHO's expert report ${ }^{34}$. In light of the environmental crisis, the importance of safe and sufficient water supply has never been stronger ${ }^{41}$. Estimated $17 \%$ of the world's population uses water from unprotected and remote sources, 32\% from some form of protected source and 51\% from some sort of centralized (piped) system to the dwelling or $\operatorname{plot}^{34}$. In response to increasing global and local water scarcity, there is the increasing use of sources such as recovered/ 
recycled waters, harvested rainwater and desalinated water ${ }^{34}$, with Australia and Israel being the world's leaders in water technology.

Some countries, like Israel who is one of the world'sleader inwaterdestilation, even havetheirown Ministry of Health program to restore concentrations of $\mathrm{Mg}$ in tap water to $30 \mathrm{mg} / \mathrm{L}$. By doing that and encouraging people to consume tap water they are hoping to increase dietary $\mathrm{Mg}$ consumption and have positive impact on public health ${ }^{42}$. Other than $\mathrm{Mg}$ consumption, there is a number of policies or public health campaigns across the world that focus on promoting water consumption. For example, Australia's 2015 ACT School Food and Drink Policy was working to ensure water is the easiest choice available, including the installation of two water refill stations in each public school ${ }^{43}$. The Hungarian Aqua Promoting Programme in the Young (HAPPY) provides free availability of mineral water in the classroom $\mathrm{s}^{44}$.

DiNicolantonio et al. ${ }^{10}$ estimated the prevalence of $\mathrm{Mg}$ deficiency in the developing countries to be $15-20 \%$. Recent data indicates that around $10-30 \%$ of the population has subclinical Mg deficiency ${ }^{10}$. People who drink hard water in comparison to those drinking soft water tend to have lower blood pressure and lower risk of cardiovascular diseases, including heart attacks and strokes ${ }^{10}$. Meta-analysis of 11 prospective cohort studies found an inverse relation between circulating levels of $\mathrm{Mg}$ and incidence of coronary heart diseases, hypertension and type 2 diabetes ${ }^{18}$. Cross-sectional study by Sun et al. ${ }^{45}$ concluded that dietary Mg consumption was inversely associated with the risk of depression. Despite growing number of research, consensus opinion is that more well designed, controlled and long-term studies are needed to confirm this inverse relation ${ }^{17,45,46}$.

\section{Physicaly Active Individuals in Focus}

The overall percentage of insufficient physicaly active adults in 2016 was $27.5 \%$ based on the data from 168 countries, and this trend had only marginaly dropped in comparison to $2001^{47}$. However, the trend is positive in men $(25.5 \%$ vs $23.4 \%$ of inactive men in 2001 and 2016 , respectively $)^{47}$. People are becoming more aware of health benefits physical activity has, especially in welldeveloped countries. This is reflected in the steady rise of people who regulary engage in some sort of physical activity. For example, in the US, the total number of visits to the gym grew by $45 \%$, from 4.6 billion in 2010 to 6.7 billion in $2019^{48}$. In 2018, the estimated value of the entire physical activity economy was $\$ 828.2$ billion globally ${ }^{49}$.

Physically active individuals are at increased risk of $\mathrm{Mg}$ deficiency due to increased needs and loss ${ }^{50,51}$. Physical activity regulates $\mathrm{Mg}$ distribution and utilization ${ }^{52}$, translocating Mg from plazma to adipocites and skeletal muscle. The amount of translocated Mg depends on the level of energy expenditure and ATP synthesis. With long-term endurance activity serum $\mathrm{Mg}$ is likely to shift to erythrocytes or muscles to support the activity and contrary, short-term activity may result in elevation of serum Mg levels ${ }^{51-53}$. Post-activity, Mg will be distributed from bones, tissue or muscles so plazma levels could be restored ${ }^{7}$. In other words, exercise leads to a temporary redistribution, not $\mathrm{Mg}$ deficiency ${ }^{19}$. However, long-tern Mg deficiency observed as low plasma consentrations, during prolonged strenuous activity increases $\mathrm{Mg}$ reqirements ${ }^{6,19,54}$.

Prolonged periods of physical activity may cause increased mineral loss through perspiration and excreti$\mathrm{on}^{52,53}$. Mg excretion by urine increases after physical activity due to elevated levels of lactic acid ${ }^{19}$. Surface losses through sweat can be a significant contributor factor for Mg deficiency especially under "extreme" conditions (heat, interval exercise, stress). Mg loss in sweat varies $^{1}$, from only $3.4 \mathrm{mg} / \mathrm{L}$ in hot dry environment to $12-60 \mathrm{mg} / \mathrm{L}$ in hot humid environment ${ }^{6}$. Another study found concentrations of $7.3 \mathrm{mg} / \mathrm{L} \mathrm{Mg}$ in male sweat after exercising. That concentration decreased to $4.1 \mathrm{mg} / \mathrm{l}$ after 10 days of acclimation ${ }^{1,54}$. On the other hand, an average person in non-hot or humid environment loses less than $5 \mathrm{mg}$ of $\mathrm{Mg}$ per day ${ }^{1}$. Still, sweat losses are not taken into consideration when $\mathrm{Mg}$ recommendations (Table 2) for physicaly active individuals were set ${ }^{53}$. Yet, studies consistently show that young and elite athletes consume less Mg then recommended ${ }^{56-60}$.

Partially, this may be due to general shift in diet quality, nutrient-dense foods (fruits, vegetables, whole grains, etc.) are changed for energy-dense foods, including sports drinks and sodas ${ }^{51}$. In general, athletes with restricted energy intake or athletes that are on specific dietary programs, which eliminate one or several food groups $^{19}$. This indicates the need for sports nutrition counseling especially when it comes to younger and elite athletes. Restricted energy intake is usually associated with sports which require weight control, like 
combat sports, wrestling, dance, gymnastics, etc. ${ }^{51}$. Athletes and active individuals should take additional 10 to $20 \% \mathrm{Mg}$ of the recommendation for their gender and age group. For male athletes consumption under $260 \mathrm{mg} /$ day, and $220 \mathrm{mg} /$ day for female athletes, may impact the performance ability ${ }^{6,51}$. Supplementary $\mathrm{Mg}$ was studied as a potential ergogenic aid ${ }^{19,52,61}$. Review by Zang et al. ${ }^{51}$ concluded that exercise performance may be compromised in $\mathrm{Mg}$ deficient individuals. However, when vitamin and mineral status is adequate, studies fail to provide supporting evidence backing up supplementation's role on athletic performance ${ }^{54}$.

Even thouh rates of supplement use vary greatly across countries ${ }^{62}$, gym attendees tend to use a variety of supplements more often - in European countries estimated $30 \%$ to $70 \%$ of gym attendees use supplements ${ }^{63}$. This practice poses a number of health risks, mainly due to the lack of knowledge about potential side effects and consequences of supplement use, especially long-term use ${ }^{64}$, as well as disinformation shared by unprofessionals through social networks ${ }^{63,65,66}$.

\section{Conclusion}

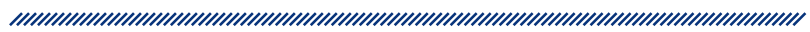

As the fourth most abundant cation in the body, $\mathrm{Mg}$ plays a number of vital roles on cellular metabolism and the overall health. Its deficiency, despite its high abundance in a variety of foods, and especially water, affects up to one third of population globally. Magnesium deficiency has been associated with hypertension, cardiovascular diseases, including heart attacks and stroke, diabetes, osteoporosis, to mention some. Around the globe, public health interventions focused on $\mathrm{Mg}$ content in water are aiming to overcome the burden of Mg deficiency, particularly efficiently in Israel and Australia. Tap water in Croatia has low Mg content, but contributes to the total daily water intake with around $40 \%$. Unlike still bottled waters, most of the bottled carbonated waters on Croatia's market contain significant amounts of Mg. Physically active individuals stand out as a population group at a particularly high risk of Mg deficiency. As public awareness of health benefits of physical activity improves, more people engage in various forms of physical activity, which is especially evident in the number of gym attendees. This group is par- ticularly prone to supplement use but highly vulnerable to their improper use, due to lack of knowledge about the side-effects, and misinformation shared through social media. More effort should be put in improving public knowledge on water as the most important Mg source, rising awareness on population groups at risk of $\mathrm{Mg}$ deficiency as well as on dangers of improper $\mathrm{Mg}$ supplementation.

\section{References}

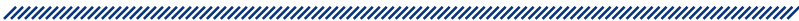

1. Nielsen FH. Magnesium: Basic Nutritional Aspects. In: Collins JF (ed.) Molecular, Genetic, and Nutritional Aspects of Major and Trace Minerals. London: Academic Press, Elsevier; 2017. p. 307-317.

2. Mazur A, Maier JAM. Magnesium. In: Caballero B, Finglas PM, Toldrá F (eds.) Encyclopedia of Food and Health. Oxford: Academic Press, Elsevier; 2016. p. 587-592.

3. Nielsen FH. Dietary Magnesium and Chronic Disease. Adv Chronic Kidney Dis. 2018; 25(3):230-5. doi: 10.1053/j. ackd.2017.11.005.

4. Čepelak I, Dodig S, Čulić O. Magnesium - more than a common cation. Medical Sciences. 2013;39:47-68.

5. Jahnen-Dechent W, Ketteler M. Magnesium Basics. Clin Kidney J. 2012;5(Suppl 1):i3-i14. doi: 10.1093/ndtplus/sfr163.

6. Nielsen FH, Lukaski HC. Update on the relationship between magnesium and exercise. Magnes Res. 2006;19(3):180-9.

7. Al Alawi AM, Majoni SW, Falhammar H. Magnesium and Human Health: Perspectives and Research Directions. Int J Endocrinol. 2018;2018:9041694. doi: 10.1155/2018/9041694

8. Ahmed F, Mohammed A. Magnesium: The Forgotten Electrolyte - A Review on Hypomagnesemia. Med Sci (Basel). 2019;7(4):56. doi: 10.3390/medsci7040056.

9. Touyz RM. Magnesium in clinical medicine. Front Biosci. 2004;9:1278-93. doi: 10.2741/1316.

10. DiNicolantonio JJ, O’Keefe JH, Wilson W. Subclinical magnesium deficiency: a principal driver of cardiovascular disease and a public health crisis. Open Heart. 2018; 5(1):e000668. doi: 10.1136/openhrt-2017-000668.

11. Barbagallo M, Dominguez LJ. Magnesium and type 2 diabetes. World J Diabetes. 2015;6(10):1152-7. doi: 10.4239/ wjd.v6.i10.1152.

12. Zhang X, Li Y, Del Gobbo LC, Rosanoff A, Wang J, Zhang W, et al. Effects of Magnesium Supplementation on Blood Pressure: A Meta-Analysis of Randomized Double-Blind Placebo-Controlled Trials. Hypertension 2016;68(2):32433. doi: 10.1161/HYPERTENSIONAHA.116.07664.

13. Kass L, Weekes J, Carpenter L. Effect of magnesium supplementation on blood pressure: a meta-analysis. Eur J Clin Nutr. 2012;66 (4):411-8. doi: 10.1038/ejcn.2012.4. 
14. Botturi A, Ciappolino V, Delvecchio G, Boscutti A, Viscardi B, Brambilla P. The Role and the Effect of Magnesium in Mental Disorders: A Systematic Review. Nutrients. 2020;12(6):1661. doi: 10.3390/nu12061661.

15. Dolati S, Rikhtegar R, Mehdizadeh A, Yousefi M. The Role of Magnesium in Pathophysiology and Migraine Treatment. Biol Trace Elem Res 2020;196(2):375-83. doi: 10.1007/s12011-019-01931-z.

16. Tucker KL. Osteoporosis prevention and nutrition. Curr Osteoporos Rep 2009;7(4):111-7. doi: 10.1007/s11914009-0020-5.

17. He K, Lewis Tsinovoi C. Magnesium intake and chronic disease in humans. In: Collins JF (ed.) Molecular, Genetic, and Nutritional Aspects of Major and Trace Minerals. London, UK: Academic Press, Elsevier; 2017. p. 333-342.

18. Wu J, Xun P, Tang Q, Cai W, He K. Circulating magnesium levels and incidence of coronary heart diseases, hypertension, and type 2 diabetes mellitus: a meta-analysis of prospective cohort studies. Nutr J. 2017;16:60. doi: 10.1186/s12937-017-0280-3

19. Vranešić Bender D, Zupčić M, Vlahek P. Use of Magnesium in Exercise and Increased Physical Activity. Medicus 2019;28(2):279-84.

20. Bylund DB. Magnesium. In: Caplan M (ed.) Reference Module in Biomedical Sciences. Elsevier Inc.; 2018.

21. Romani AMP. Cellular magnesium homeostasis. Arch Biochem Biophys. 2011;512(1):1-23. doi: 10.1016/j. abb.2011.05.010.

22. Piovesan D, Profiti G, Martelli PL, Casadio R. The human „magnesome“: detecting magnesium binding sites on human proteins. BMC Bioinformatics. 2012;13(Suppl 14):S10. doi: 10.1186/1471-2105-13-S14-S10

23. Reddy ST, Soman SS, Yee J. Magnesium balance and Measurement. Adv. Chronic Kidney Dis. 2018; 25(3):224-9. doi: 10.1053/j.ackd.2018.03.002.

24. Gröber U, Schmidt J, Kisters K. Magnesium in Prevention and Therapy. Nutrients 2015; 7(9):8199-226. doi: 10.3390/nu7095388.

25. Houillier P. Mechanisms and regulation of renal magnesium transport. Annu Rev Physiol. 2014;76:411-30. doi: 10.1146/annurev-physiol-021113-170336.

26. Razzeque MS. Magnesium: Are we consuming enough? Nutrients 2018;10(12):1863. doi: 10.3390/nu10121863.

27. Shils ME. Experimental human magnesium depletion. Medicine (Baltimore) 1969; 48(1):61-85. doi: 10.1097/00005792196901000-00003.

28. European Food Safety Authority: Dietary Reference Values for the Eu; DRV Finder, 2019 https://www.efsa.europa. eu/en/interactive-pages/drvs [27.01.2020.]

29. Kaić-Rak A, Antonić Degač K. Tablice o sastavu namirnica i pića. Zagreb, Croatia: Zavod za zaštitu zdravlja SR Hrvatske; 1990.

30. Pouteau E, Kabir-Ahmadi M, Noah L, Mazur A, Dye L, Hellhammer J, et al. Superiority of magnesium and vitamin B6 over magnesium alone on severe stress in healthy adults with low magnesemia: A randomized, single- blind clinical trial. PLoS One. 2018; 13(12):e0208454. doi: 10.1371/journal.pone.0208454.

31. Munoz CX, Johnson EC. Hydration for Athletic Performance. In: Nutrition and Enhanced Sports Performance. Academic Press Elsevier; 2019. p. 533-543.

32. Armstrong LE, Johnson EC. Water intake, water balance, and the elusive daily water requirement. Nutrients. 2018;10(12):1928. doi: 10.3390/nu10121928.

33. European Food Safety Authority Scientific Opinion on Dietary Reference Values for water. EFSA Journal. 2010;8(3):1459-507.

34. World Health Organization. Calcium and magnesium in drinking-water: public health significance. Geneva: WHO; 2009.

35. Nissensohn M, Castro-Quezada I, Serra-Majem L. Beverage and water intake of healthy adults in some European countries. Int J Food Sci Nutr. 2013;64(7):801-5. doi: 10.3109/09637486.2013.801406.

36. Marković Ž. Effect of water hardness and magnesium on the incidence of cardiovascular diseases. Master thesis. Zagreb: University of Zagreb, School of Medicine; 2016.

37. EFSA The Comprehensive European Food Consumption Database. Available from: https://www.efsa.europa.eu/ en/food-consumption/comprehensive-database [Accessed $11^{\text {th }}$ February 2020]

38. Croatian Food Agency. Scientific opinion on the effect of water quality for human consumption on nutritional value of infant milk preparations. Osijek: Croatian Food Agency; 2016.

39. World Health Organization. Hardness in drinking-water. Geneva: WHO; 2011.

40. Azoulay A, Garzon P, Eisenberg MJ. Comparison of the Mineral Content of Tap Water and Botteled Waters. J Gen Intern Med. 2001;16(3):168-75. doi: 10.1111/j.15251497.2001.04189.x.

41. EEA, European Environment Agency (2016): The problems of water stress. EFSA; 2016. Available from: https:// www.eea.europa.eu/publications/92-9167-025-1/page003.html [Accessed $11^{\text {th }}$ February 2020]

42. https://www.health.gov.il/English/Topics/FoodAndNutrition/Nutrition/Adequate_nutrition/Pages/magnesium.aspx Accessed January 29, 2020.

43. ACT Government. The ACT Public School Food and Drink Policy 2015 Fact Sheet. Available from: https://www. education.act.gov.au/publications_and_policies/School-and-Corporate-Policies/school-administration-andmanagement/food-and-drink?a $=692297 \quad\left[\right.$ Accessed $9^{\text {th }}$ February 2021].

44. https:/ec.europa.eu/jrc/en/health-knowledge-gateway/ promotion-prevention/nutrition/water. Accessed January 29, 2020.

45. Sun C, Wang R, Li Z, Zhang D. (2019): Dietary magnesium intake and risk of depression. J Affect Disord. 2019;246:627-32. doi: 10.1016/j.jad.2018.12.114.

46. La SA, Lee JY, Kim DH, Song EL, Park JH, Ju SY. Low magnesium levels in adults with metabolic syndrome: a 
meta-analysis. Biol Trace Elem Res. 2015;170(1):33-42. doi: 10.1007/s12011-015-0446-9.

47. Guthold R, Stevens GA, Riley LM, Bull FC. Worldwide trends in insufficient physical activity from 2001 to 2016: a pooled analysis of 358 population-based surveys with 1.9 million participants. Lancet Glob Health 2018;6(10):e107786. doi: 10.1016/S2214-109X(18)30357-7.

48. Rizzo N. 77 Gym Membership Statistics, Facts, and Trends [2019/2020]. Available from: https://runrepeat.com/ gym-membership-statistics\#gym-attendance-statistics [Accessed 9th February 2021].

49. Global Wellness Institute. Move To Be Well: The Global Economy of Physical Activity. Global Wellnes Institute; 2019. Available from: https://globalwellnessinstitute. org/industry-research/global-economy-physical-activity/ [Accessed $9^{\text {th }}$ February 2021].

50. Bohl CH, Volpe SL. Magnesium and Exercise. Crit Rev Food Sci Nutr. 2002;42(6):533-63. doi: 10.1080/20024091054247.

51. Laires MJ, Monteiro PC, Matias CN, Santos DA, Silva AM, Bicho M. Magnesium status and exercise performance in athletes. Trace Elem Electroly. 2014;31:13-20. doi: 10.5414/TEX01304.

52. Zang Y, Xun P, Wang R, Mao L, He K. Can Magnesium Enhance Exercise Performance? Nutrients. 2017;9:946-56. doi: 10.3390/nu9090946

53. Rakhra G, Masih D, Vats A, Verma SK, Singh VK, Tomar Rana $\mathrm{R}$, et al. Effect of physical activity and age on plasma copper, zinc, iron and magnesium concentration in physically active healthy males. Nutrition. 2017;4344:75-82. doi: 10.1016/j.nut.2017.06.005.

54. Kerksick MC, Wilborn CD, Roberts MD, Smith-Ryan A, Kleiner SM, Jager R, et al. ISSN exercise \& sport nutrition review update: research \& recommendations. J Int Soc Sports Nutr. 2018; 15(1):38. doi: 10.1186/s12970-018-0242-y.

55. Chinevere TD, Kenefick RW, Cheuvront SN, Lukaski HC, Sawka MN. Effect of heat acclimation on sweat minerals. Med. Sci. Sports Exerc. 2008; 40(5):886-91. doi: 10.1249/ MSS.0b013e3181641c04.

56. Volpe SL. Magnesium and athlete. Curr Sports Med Rep. 2015;14(4):279-83. doi: 10.1249/JSR.0000000000000178.

57. Silva MR, Paiva T. Low energy availability and low body fat of female gymnasts before an international competition. Eur J Sport Sci. 2014;15(7):591-9. doi: 10.1080/17461391.2014.969323.
58. Heaney S, O'Connor H, Gifford J, Naughton G. Comparison of strategies for assessing nutritional adequacy in elite female athletes' dietary intake. Int J Sport Nutr Exerc Metab. 2010;20(3):245-56. doi: 10.1123/ijsnem.20.3.245.

59. Wierniuk A, Włodarek D. Estimation of energy and nutritional intake of young men practicing aerobic sports. Rocz Panstw Zakl Hig. 2013;64(2):143-8.

60. Santos DA, Matias CN, Monteiro CP, Silva AM, Rocha PM, Minderico CS, et al. Magnesium intake is associated with strength performance in elite basketball, handball and volleyball players. Magnes Res. 2011; 24(4):215-9. doi: 10.1684/mrh.2011.0290.

61. Cinar V, Nizamlioglu M, Mogulkoc R, Baltaci AK. Effects of Magnesium Supplementation on Blood Parameters of Athletes at rest and After Exercise. Biol Trace Elem Res. 2007; 115(3):205-12. doi: 10.1007/BF02685995.

62. Skeie G, Braaten T, Hjartåker A, Lentjes M, Amiano P, Jakszyn $P$, et al. Use of dietary supplements in the European Prospective Investigation into Cancer and $\mathrm{Nu}$ trition calibration study. Eur J Clin Nutr 2009;63(Suppl 4):S226-38. doi: 10.1038/ejcn.2009.83.

63. Kiss A, Pfeiffer L, Popp J, Oláh J, Lakner Z. A Blind Man Leads a Blind Man? Personalised Nutrition-Related Attitudes, Knowledge and Behaviours of Fitness Trainers in Hungary. Nutrients 2020;12(3):663. doi: 10.3390/ nu12030663.

64. Druker I, Gesser-Edelsburg A. Identifying and assessing views among physically-active adult gym members in Israel on dietary supplements. J Int Soc Sports Nutr 2017;14:37. doi: 10.1186/s12970-017-0194-7.

65. Stollfuß S. Communitainment on Instagram: Fitness Content and Community-Driven Communication as Social Media Entertainment. SAGE Open 2020;10(2):1-12. doi: 10.1177/2158244020919535.

66. Sidhu S. Social Media, Dietetic Practice and Misinformation: A triangulation research. Journal of Content, Community \& Communication 2018;8(4):29-34. doi: 10.31620/JCCC.12.18/06. 


\section{MAGNEZIJ IZ PERSPEKTIVE JAVNOG ZDRAVSTVA}

1 Lidija Šoher

1 Ines Banjari

1 Zavod za ispitivanje hrane i prehrane, Prehrambenotehnološki fakultet Osijek, Sveučilište Josipa Jurja Strossmayera u Osijeku, Hrvatska

\section{Sažetak}

Magnezij je kofaktor za više od 300 enzima koji ima ključnu ulogu u energetskom metabolizmu, homeostazi elektrolita, metabolizmu kostiju te regulira brojne fiziološke procese kao što su kontrakcija mišića, neuromuskulatorne funkcije, kontrola glikemije i krvnog tlaka. Deficit magnezija predstavlja čimbenik rizika za cijeli niz zdravstvenih problema, od kardiovaskularnih bolesti, hipertenzije, dijabetesa, do anksioznosti i drugih mentalnih poremećaja, migrena i osteoporoze. Posebice zabrinjava subklinički oblik deficita magnezija za koji se procjenjuje kako pogađa do $30 \%$ populacije. Preporučeni unos magnezija za odrasle osobe je $300 \mathrm{mg}$ za žene i 350 mg za muškarce. lako je široko rasprostranjen u hrani, posebice tamno zelenom lisnatom povrću, orašastim plodovima i sjemenkama, najveći doprinos dnevnom unosu magnezija dolazi iz vode. Upravo je voda u fokusu javnozdravstvenih intervencija koje imaju za cilj poboljšati status magnezija u populaciji, posebice u Izraelu i Australiji. Dodaci prehrani postaju sve važniji izvor magnezija, posebice među tjelesno aktivim osobama. S porastom svijest javnosti o zdravstvenim dobrobitima fizičke aktivnosti raste i broj (rekreativno) tjelesno aktivnih osoba. Iako rizik od deficita magnezija raste s fizičkom aktivnošću, pogrešno uzimanje dodataka prehrani uslijed nedostatnog znanja i dezinformacija koje se dijele na društvenim mrežama, povećava se mogućnost za negativne posljedice na zdravlje i tjelesnu sposobnost.

Ključne riječi: magnezij, deficit, javno zdravlje, voda, fizička aktivnost 